Pteridines

Vol. 5, 1994, pp. 95-101

\title{
Glyceryl-ether Monooxygenase [EC 1.14.16.5] Part VII Effects of Alkyl Phosphocholines and Acyl L- $\alpha$-lyso-Phosphatidylcholines Detergents on Enzyme Activity
}

\author{
Toshikatsu Kurisu, ${ }^{\dagger}$ Hiroyasu Taguchi, ${ }^{\dagger \dagger}$ Bela Paal, $={ }^{\text {Nan }}$ Yang $^{\ddagger}$ and Wilfred L.F. Armarego ${ }^{\ddagger}$ \\ ${ }^{\dagger}$ Department of Applied Microbial Technology, The Kumamoto Institute of Technology, 4-22-1 Ikeda, \\ Kumamoto, 860, Japan \\ ${ }^{\dagger \dagger}$ Department of Natural Science, Kyoto Women's University, 35 Kitahiyoshi-cho, Imakumano, \\ Higashiyama-ku, Kyoto 605, Japan \\ \#Division of Biochemistry and Molecular Biology, John Curtin School of Medical Research, \\ The Australian National University, G.P.O. Box 334, Canberra City, ACT 2601, Australia
}

(Received March 14, 1994)

\begin{abstract}
Summary
The effects of the ionic detergents dodecyl, tetradecyl, hexadecyl and octadecyl phosphocholines, and dodecanoyl, tetradecanoyl, hexadecanoyl and octadecanoyl L- $\alpha$-lyso-phosphatidylcholines on the enzyme activity of glyceryl-ether monooxygenase are reported. All these detergents inhibit the monooxygenase at concentrations above a threshold value which is above the relative critical micelle concentrations implying that the micelles interact passively with the microsomal membrane below the threshold concentration. The kinetics of inhibition by the $\mathrm{C} 14$ and $\mathrm{C} 16$ detergents above the threshold concentrations have been selected for study and are found to be competitive with apparent $\mathrm{Ki}$ values in the range 316-365 $\mu \mathrm{M}$. The apparent $\mathrm{Km}$ and Vmax values for $R S$-batyl alcohol with $6-\mathrm{MePH}_{4}$ as cofactor in the presence of the choline detergents (at or below the threshold inhibiting concentrations) are in the range $24-44 \mu \mathrm{M}$ and $46-64 \mathrm{nmoles} / \mathrm{min} . \mathrm{mg}$ of monooxygenase protein respectively. These data are compared and discussed with data reported for the monooxygenase in the presence of the non-ionic detergent Mega- 10 .
\end{abstract}

Keywords : Glyceryl-ether monooxygenase, Activity, $K \mathrm{~m}$ and Vmax values, Inhibition, Alkyl phosphocholines, Acyl L-a-lyso-phosphatidylcholine, Critical micelle concentration,

\footnotetext{
\& Author to whom correspondence should be addressed. Enzymes : Bovine liver catalase [EC 1.11.1.6]. Dihydropteridine reductase (DHPR), NAD (P)H : $q-7$, 8-dihydropterin oxidoreductase [EC 1.6.99.7]. Glyceryl-ether monooxygenase, 1alkyl-sn-glycerol, tetrahydropterin : oxygen oxidoreductase [EC 1.14.16.5]. Abbreviations : $6-\mathrm{MePH}_{4}=R S-6$-methyl-5, 6, 7, 8-tetrahydropterin; lyso-PAF = 3-(1-hexadecyloxy)-2-hydroxypropane-1-phosphocholine; Mega-10 $=\mathrm{N}$-methyl-N-decanoylglucamide; $12 \mathrm{PC}=$ dodecyl phosphocholine; $14 \mathrm{PC}=$ tetradecylphosphocholine; $16 \mathrm{PC}=$ hexadecyl phosphocholine; $18 \mathrm{PC}=$ octadecyl phosphocholine; $12 \mathrm{LPC}=$ dodecanoyl (lauroyl) L- $\alpha$ lys 0 -phosphatidylcholine; $14 \mathrm{LPC}=$ tetradecanoyl (myristoyl) L- $\alpha$-lyso-phosphatidylcholine; $16 \mathrm{LPC}=$ hexadecanoyl (palmitoyl) $\mathrm{L}-\alpha-$-lyso-phosphatidylcholine; $18 \mathrm{LPC}=$ octadecanoyl (stearoyl) $\mathrm{L}-\alpha-l y$ so-phosphatidylcholine; $\mathrm{CMC}=$ critical micelle concentration.
}

\section{Introduction}

The rat liver microsomal enzyme, glyceryl-ether monooxygenase, hydroxylates the $\alpha$-methylene group of the alkyl sidechain (e.g. C16, C18) of 1-glyceryl-ethers (1) in the presence of oxygen and a tetrahydropterin (2) (Scheme 1)(1). A direct spectrophotometric assay for this enzyme has been developed and has been very useful for studying the kinetic parameters of a variety of substrates $(2,3)$ and was used to deternine some important aspects of the stoichiometry (4). The major difficulty that had to be overcome for this assady was the general insolubility of the ether lipid sub. strates in water or aqueous buffers. This has been 


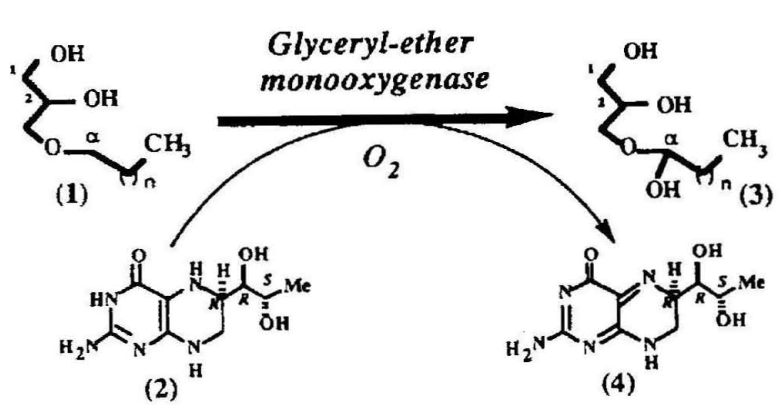

Scheme 1
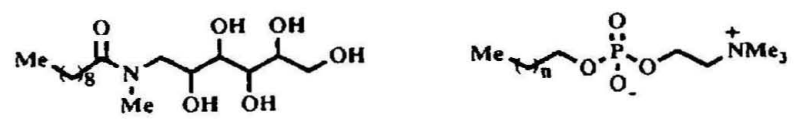

(5) Mega-10

(6) $\mathrm{n}=10,12 \mathrm{PC}$

(7) $\mathrm{n}=12,14 \mathrm{PC}$

(8) $\mathrm{n}=14,16 \mathrm{PC}$

(9) $\mathrm{n}=16,18 \mathrm{PC}$

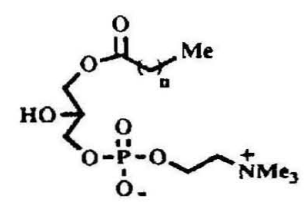

(10) $\mathrm{n}=10,12 \mathrm{LPC}$

(11) $\mathrm{n}=12,14 \mathrm{LPC}$

(12) $n=14,16 L P C$

(13) $\mathrm{n}=16,18 \mathrm{LPC}$

achieved by using detergents in water or aqueous buffers. Solubilisation of the ether-lipid stock solutions containing detergents was completed by gentle warming and/or sonication for short periods, and the clear solutions were stable for various periods of time (3). In all cases these solutions were clear before assaying. A most satisfactory detergent for this purpose was the non-ionic amide Mega-10 (5)(5) which produced aqueous solutions of ether-lipids that were clear for extended periods.

The solutions did become turbid, however, after periods of time but could be made clear again by gentle warming, or sonication, without in any way affecting the enzyme activity with these substrates. Solutions of the substrate 3-1'-octadecylpropan-1, 2diol (batyl alcohol, $1, \mathrm{n}=16$ ) in Mega-10 had maximum enzyme activities with concentrations of Mega10 up to $c a 6 \mathrm{mM}(0.2 \%)$. However, the enzyme was inhibited at higher concentrations of detergent. Kinetic studies revealed that Mega-10 was inhibiting enzyme activity in a non-competitive manner, and because inhibition occurred at concentrations above the CMC of Mega-10 (7.15 mM), it was deduced that the inhibiting species were Mega-10 micelles. Since $R S$ -
lyso-PAF was an active substrate well above its CMC value in the absence of any detergent, and batyl alcohol was active in Mega-10 solutions below the CMC of Mega-10, it was concluded that the active substrates were in micelle form for lyso-PAF and in mixed micelle form for batyl alcohol-Mega-10 solutions (6).

In the present work we describe studies with ionic detergents related to phosphocholines, namely alkyl phosphocholines (6-9) and acyl L- $\alpha$-lyso-phosphatidy lcholines (10-13) with $\mathrm{C} 12, \mathrm{C} 14, \mathrm{C} 16$ and $\mathrm{C} 18$ fatty chains. These cholines were investigated because they were similar in structure to membrane lipids without monooxygenase activity, and because tetradecyl phosphocholine (8) and 1-lauroylpropanediol-1, 3 -phosphocholine were used to solubilise 1-alkyl glyceryl-ethers for the coupled (continuous spectrophotometric) assay for glyceryl-ether monooxygenase with dihydropteridine reductase in the presence of NADH developed by Eibl and coworkers $(7,8)$. When batyl alcohol was used as substrate and $6-\mathrm{MePH}_{4}$ as cofactor these detergents behaved like Mega-10 except that they inhibited the monooxygenase in a $\mathrm{co}$ mpetitive manner with only minor differences in apparent $\mathrm{Ki}$ values between the two sets of detergents. Also, unlike with Mega-10, the concentration of choline detergent at which monooxygenase inhibition occurred was well above the CMC of the respective cholines.

\section{Materials and Methods}

RS-Batyl alcohol (RS-3-1'-octadecyloxypropan-1, 2diol, referred to as batyl alcohol), Mega-10, lauroyl-, myristoyl-, palmitoyl- and stearoyl-L- $\alpha-l y$ so-phosphocholines, dodecan-1-ol, tetradecan-1-ol, hexadecan-1ol and octadecan-1-ol, and bovine catalase (Sigma), ethanolamine (Fluka) and magnesium 8-anilino-1-naphthalene sulphonate (Kodak) were purchased and $R S$-6-methyl-5,6,7,8-tetrahydropterin (6- $\left.\mathrm{MePH}_{4}\right)$ hydrochloride was prepared as before (9). The microsomal glyceryl-ether monooxygenase was prepared from male Wistar rat livers as before (3) and had consistent specific activities of $c a 27$ nmoles/min.mg protein in the standard assay (below). A double beam UV-VIS spectrometer (Cary 118) was used for kinetic measurements with the cuvette holders thermostated at $25^{\circ} \mathrm{C}$, and fluorescence measurements were obtained on a Perkin Elmer LS5 luminescence spectrometer. Critical micelle concentrations were determined as before using magnesium 8-anilino-1-naphthalene sulphonate as fluorescent dye $(6,10)$. IR spectra were in $\mathrm{KBr}$ discs and measured on a Perkin Elmer 1600 Series FTIR spectrometer, and ${ }^{1} \mathrm{H}$ NMR spectra were measured on a Varian Gemini 300 spectrometer 
at $300 \mathrm{MHz}$.

\section{Syntheses of alkyl phosphocholines}

The synthesis described by Eibl and Engel (11) for hexadecyl phosphocholine (16 PC) was adopted with slight modifications for the preparation of dodecyl (12 PC), tetradecyl (14 PC), hexadecyl (16 PC) and octadecyl (18 PC) phosphocholines, and details for $14 \mathrm{PC}$ are given here. To $\mathrm{POCl}_{3}$ (14.7 g, 96 mmoles) in dry THF $(8 \mathrm{ml})$ was added a solution of $\mathrm{Et}{ }_{3} \mathrm{~N}(8.9 \mathrm{~g}$, 88 mmoles $)$ and tetradecan-1-ol (17.1 g, 80 mmoles) in dry THF $(80 \mathrm{ml})$ in an ice bath $\left(<15^{\circ} \mathrm{C}\right)$ and stirred at room temperature for $1 \mathrm{~h}$. A solution of ethanolamine (5.9 g. 97 mmoles) and $\mathrm{Et}_{3} \mathrm{~N}$ (19.6 g, $194 \mathrm{mmo}^{-}$ les) was added to the above mixture keeping the temperature below $30^{\circ} \mathrm{C}$, and; then stirred at room temperature for $1 \mathrm{~h}$ followed by $40^{\circ} \mathrm{C}$ for $1 \mathrm{~h}$. The mixture was filtered and the filtrate was evaporated in vacuo. The residue was dissolved in acetic acid $(30 \mathrm{ml})$ and water $(15 \mathrm{ml})$ was added. The mixture was heated at $70^{\circ} \mathrm{C}$ for $30 \mathrm{~min}$ and cooled. Acetone $(600 \mathrm{ml})$ was added and the mixture was stirred at room temperature for $15 \mathrm{~h}$. The supernatant was removed by decantation and the residue was stirred again with acetone $(600 \mathrm{ml})$ for $3 \mathrm{~h}$. The colourless solid was collected, washed with acetone and air-dried to give tetradecyl phospho-ethanolamine $(22.1 \mathrm{~g}, 82 \%)$. This ethanolamine ( $6.74 \mathrm{~g}, 20$ mmoles) was dissolved in $\mathrm{CH}_{2} \mathrm{Cl}_{2}(60 \mathrm{ml})$ and propan-2-ol $(24 \mathrm{ml})$, and was warmed to $40^{\circ} \mathrm{C}$. A solution of $\mathrm{K}_{2} \mathrm{CO}_{3}$ (2.76 g, 20 mmoles) in water $(4 \mathrm{ml})$ was added to the mixture followed by $\mathrm{Me}_{2} \mathrm{SO}_{4}(2.3 \mathrm{~g}, 18$ mmoles$)$ in propan-2-ol (1 ml) at $40^{\circ} \mathrm{C}$ over a period of $1 \mathrm{~h}$, and then stirred at $40^{\circ} \mathrm{C}$ for a further hour. The addition of $\mathrm{K}_{2} \mathrm{CO}_{3}$ and $\mathrm{Me}_{2} \mathrm{SO}_{4}$ was repeated twice more using the same quantities and then again once more using half the quantities but the same time period. After the mixture was cooled to room temperature without stirring, the upper layer was collected and evaporated in vacuo. The residue was extracted with $\mathrm{EtOH}$ and the extract evaporated in vacuo. The residue was extracted with warm propan-2-ol and again the extract was evaporated to dryness in vacuo. The residue was washed twice with acetone at room temperature with stirring, and the solid was collected, washed with acetone and air-dried to give pure $14 \mathrm{PC}(6.1 \mathrm{~g}, 80.5 \%)$, m.p. $>240^{\circ}$ decomp. (Found : N, 3.10; P, 7.64. $\mathrm{C}_{19} \mathrm{H}_{42} \mathrm{NO}_{4} \mathrm{P} .4 \mathrm{H}_{2} \mathrm{O}$ requires $\mathrm{N}, 3.33 ; \mathrm{P}, 7.36 \%$ ). Similarly prepared were 12 PC with m.p. $240^{\circ}$ decomp. (Found : N, 3.18; P, 7.41. $\mathrm{C}_{17} \mathrm{H}_{38} \mathrm{NO}_{4} \mathrm{P} .6 \mathrm{H}_{2} \mathrm{O}$ requires $\left.\mathrm{N}, 3.27 ; \mathrm{P}, 7.23 \%\right) ; 16 \mathrm{PC}$ with m.p. $240^{\circ}$ decomp. (Found : N, 2.52; P, 6.31. C 21 $\mathrm{H}_{46} \mathrm{NO}_{4} \mathrm{P} .11 \mathrm{H}_{2} \mathrm{O}$ requires $\left.\mathrm{N}, 2.79 ; \mathrm{P}, 6.16 \%\right)$; and 18 PC with m.p. $240^{\circ}$ decomp. (Found : N, 2.55; P, 5.93.
$\mathrm{C}_{23} \mathrm{H}_{50} \mathrm{NO}_{4} \mathrm{P} .10 \mathrm{H}_{2} \mathrm{O}$ requires $\mathrm{N}, 2.77 ; \mathrm{P}, 6.13 \%$ ). The IR spectra all had $v: 970,1065,1087$ (s, P-O-Calkyl), $1224(\mathrm{P}=\mathrm{O}), 1472,1464(\mathrm{OH}$ bend), 2852 and 2923 (CHstr) and $3446\left(\mathrm{OH}\right.$ from $\left.\mathrm{H}_{2} \mathrm{O}\right) \mathrm{cm}^{-1}$

All four alkyl phosphocholines were soluble in $\mathrm{CDCl}_{3}$ and had $300 \mathrm{MHz}{ }^{1} \mathrm{H}$ NMR spectra which were almost identical to each other except for the sum of the integrals of the methylene groups of the long alkyl chain other than the 1 - and $2-\mathrm{CH}_{2}$ groups; the $\delta$ values were $0.88 \mathrm{t} \mathrm{J} 6.8 \mathrm{~Hz} \omega-\mathrm{CH}_{3}$ of the alkyl chain; $1.25 \mathrm{~s}$ 3 to $\omega-1 \mathrm{CH}_{2} ; 1.56 \mathrm{~m}_{2}-\mathrm{CH}_{2} ; 3.35 \mathrm{~s} \mathrm{~N}\left(\mathrm{CH}_{3}\right)_{3} ; 3.77 \mathrm{~m}$ $1-\mathrm{CH}_{2}-\mathrm{O}$ and $1^{\prime}-\mathrm{CH}_{2} \mathrm{O}-$, and $4.26 \mathrm{~m} \quad 2-\mathrm{CH}_{2}-\mathrm{N}$ ppm downfield from tetramethylsilane. Water in the samples appeared at $4.19,4.33,3.77$ and $4.29 \mathrm{ppm}$ for $12 \mathrm{PC}, 14 \mathrm{PC}, 16 \mathrm{PC}$ and $18 \mathrm{PC}$ respectively.

\section{Enzyme activity-detergent concentration profile}

The standard assay using $0.1 \mathrm{mM}$ batyl alcohol as

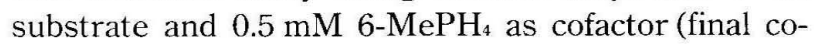
ncentration and almost saturating) was adopted (3, 6). Stock solutions ( $100 \mu \mathrm{l}, 10 \times$ concentration) of the alcohol were made in water containing the smallest concentration of choline detergent to solubilise it were added to the reaction cuvette containing $670 \mu \mathrm{l}$ of Tris-catalase $(100 \mu \mathrm{l}$ of $\mathrm{M}$ Tris- $\mathrm{HCl} \mathrm{pH} 7.5,100 \mu \mathrm{l}$ of $1 \mathrm{mg} / \mathrm{ml}$ catalase and $470 \mu \mathrm{l}$ of water), detergent solution in water $(100 \mu \mathrm{l}$, adjusted to the required concentration) and microsomal enzyme ( $30 \mu \mathrm{l}$, of 54 or $12.8 \mathrm{mg} / \mathrm{ml}$ protein). The blank cuvette contained the same ingredients without batyl alcohol. The analytical wavelength was set at $354 \mathrm{~nm}$ and the maximum recorder deflection was set at 0.02 absorbance units. At this wavelength the reaction extinction coefficient was $3440 \mathrm{M}^{-1} \mathrm{~cm},{ }^{-1}$ i.e. one absorbance unit was $0.291 \mu$ moles. $\mathrm{ml}^{-1}$ for a $1 \mathrm{~cm}$ cell pathlength (3) When a steady baseline was obtained $(2 \sim 5 \mathrm{~min})$, the reaction was initiated by adding simultaneously 5

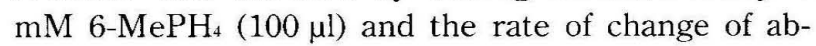
sorbance was determined from the recorder trace. The mean of reproducible runs were then plotted against the detergent concentrations (Figure 1 and 2). Prior to each set of runs, enzyme activity was measured using the standard assay (6) with Mega-10 as detergent and if that had changed from the original value all the rates were normalised to this value. Enzyme activity did not usually vary from day to day and never from the first to the last measurement during a set of runs.

\section{Measurement of the kinetic parameters}

Measurements were carried out as above except that the batyl alcohol concentrations were varied and 
Table 1. Critical Micelle concentrations of alkyl phosphocholines and acyl L- $\alpha$-lyso-phosphatidylcholines in the presence and absence of $0.1 \mathrm{mM}$ batyl alcohol in $0.1 \mathrm{M}$ Tris- $\mathrm{HCl} \mathrm{pH} 7.5$ and $22^{\circ} \mathrm{C}-25^{\circ} \mathrm{C}$.

\begin{tabular}{|c|c|c|c|c|c|}
\hline \multirow[b]{2}{*}{ Phosphocholines } & \multicolumn{2}{|c|}{$\mathrm{CMC}(\mu \mathrm{M})$} & \multirow{2}{*}{$\begin{array}{c}\text { L- } \alpha-l y \operatorname{sos} o- \\
\text { Phosphatidyl- } \\
\text { cholines }\end{array}$} & \multicolumn{2}{|c|}{$\mathrm{CMC}(\mu \mathrm{M})$} \\
\hline & -- & $\begin{array}{c}0.1 \mathrm{mM} \text { Batyl } \\
\text { alcohol }\end{array}$ & & - & $\begin{array}{c}0.1 \mathrm{mM} \text { Batyl } \\
\text { alcohol }\end{array}$ \\
\hline $\begin{array}{l}\text { Dodecyl } \\
\text { (1? PC) }\end{array}$ & $\begin{array}{c}622 \\
(0.020 \%)\end{array}$ & $\begin{array}{c}482 \\
(0.016 \%)\end{array}$ & $\begin{array}{c}\text { Lauroyl } \\
\text { (12 LPC) }\end{array}$ & $\begin{array}{c}470 \\
(0.019 \%)\end{array}$ & $\begin{array}{c}395 \\
(0.016 \%)\end{array}$ \\
\hline $\begin{array}{l}\text { Tetradecyl } \\
\text { (14 PC) }\end{array}$ & $\begin{array}{c}53 \\
(0.0018 \%)\end{array}$ & $\begin{array}{c}58 \\
(0.0020 \%)\end{array}$ & $\begin{array}{l}\text { Myristoyl } \\
\text { (14 LPC) }\end{array}$ & $\begin{array}{c}59 \\
(0.0026 \%)\end{array}$ & $\begin{array}{c}77 \\
(0.0034 \%)\end{array}$ \\
\hline $\begin{array}{l}\text { Hexadecy] } \\
(16 \mathrm{PC})\end{array}$ & $\begin{array}{c}7.2 \\
(0.0003 \%)\end{array}$ & $\begin{array}{c}22 \\
(0.0008 \%)\end{array}$ & $\begin{array}{l}\text { Palmitoyl } \\
\text { (16 LPC) }\end{array}$ & $\begin{array}{c}2.8 \\
(0.00013 \%)\end{array}$ & $\begin{array}{c}8 \\
(0.00037 \%)\end{array}$ \\
\hline $\begin{array}{l}\text { Octadecyl } \\
\text { (18 PC) }\end{array}$ & $\begin{array}{c}35 \\
(0.00014 \%)\end{array}$ & $\begin{array}{c}3.0 \\
(0.00012 \%)\end{array}$ & $\begin{array}{l}\text { Stearoyl } \\
\text { (18 LPC) }\end{array}$ & $\begin{array}{c}0.2 \\
(0.00001 \%)\end{array}$ & $\ldots$ \\
\hline Mega- $10^{b}$ & $\begin{array}{c}7150 \\
(0.25 \%)\end{array}$ & $\begin{array}{l}5720 \\
(0.20 \%)\end{array}$ & & & \\
\hline
\end{tabular}

$0.1 \mathrm{mM}$ Batyl alcohol could not be dissolved in the small amount of $18 \mathrm{LPC}$ required for the initial solution

'From ref. 3

the concentrations of choline detergents were set at or near the values which gave maximum rates (see Figure 1 and 2) for each detergent. A computer program was used to evaluate the apparent $\mathrm{Km}$ and Vmax values (12).

\section{Inhihition measuroments}

These were carried out as before (6) (see also above) and the data were evaluated using a computer program (12) to fit competitive, noncompetitive and mixed inhibition equations. The equations which gave apparent $\mathrm{Ki}$ values with the smallest errors were taken as the correct type of inhibition and agreed very well with Lineweaver-Burk plots (e.g. Figure 3).

\section{Discussion \\ Critical micelle roncentration of choline detergents}

The alkyl phosphocholines and acyl L- $\alpha$-lyso-phosphatidylcholines have ionic detergent properties because they have long fatty unhranched hydrocarbon chains with polar groups at one end. They are capable of forming micelles and we have measured the critical micelle concentrations (CMC) for the two sets of choline detergents in $0.1 \mathrm{M}$ Tris- $\mathrm{HCl} \mathrm{pH} 7.5$ as well as in the presence of $0.1 \mathrm{mM}$ batyl alcohol (Table 1 ). The conditions chosen were appropriate for other studies discussed here. In each set of detergents the $\mathrm{CMC}$ values decreased rapidly with increase of hydrocarbon chain length from $\mathrm{C} 12$ to $\mathrm{C} 18$. In $0.1 \mathrm{M}$ Tris- $\mathrm{HCl}$ the decrease in $\mathrm{CMC}$ values for the alkyl phosphocholines was about two orders of magnitude, and for the phosphatidylcholines it was greater than three orders of magnitude. It should be noted that the $\mathrm{CMC}$ values are not sharp concetrations but are concentration ranges that can be as high as $\pm 10 \%$ of the extrapolated value. With high CMC values as with $12 \mathrm{PC}$ this range was $\pm 80 \mu \mathrm{M}$, whereas with $18 \mathrm{PC}$ the range was smaller than $c a 0.5 \mu \mathrm{M}$. It was generally found that as the CMC value decreased for a particular set of detergents the change in fluorescence was sharper as the CMC value was reached, e.g. the range was of the order of $<5 \%$ of the $\mathrm{CMC}$ value for $\mathrm{C} 18$ fatty chains. In the presence of $0.1 \mathrm{mM}$ batyl alcohol the CMC values were decreased for $12 \mathrm{PC}$ and 12 LPC but increased progressively as the hydrocarbon chains increased. We had shown ${ }^{6}$ that the CMC of Mega-10 in Tris- $\mathrm{HCl}(\mathrm{pH}$ 7.5) also decreased from $7.15 \mathrm{mM}$ to $5.72 \mathrm{mM}$ when the detergent contained $0.1 \mathrm{mM}$ batyl alcohol and that below 5.72 $\mathrm{mM}$ the latter solution contained mixed batyl alcohol/Mega-10 micelles. It can be inferred that solutions of batyl alcohol and the choline detergents with concentrations below the CMC, batyl alcohol formed mixed micelles with the detergents. This is further supported by the almost insolublility of batyl alcohol in aqueous buffer; sonicated suspensions of batyl alcohol in water or aqueous buffer without detergents elicited no monooxygenase activity (3).

Monooxygenase activity $v$ s detergent concentration profiles

The profiles for the four alkyl phosphocholines (69) and the four phosphatidyl cholines (10-13) were determined using $0.1 \mathrm{mM}$ batyl alcohol as substrate 


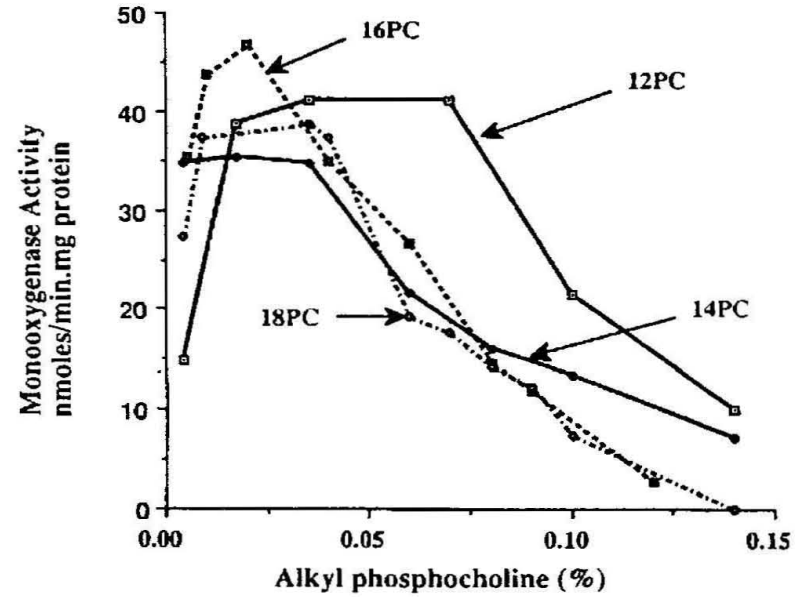

Figure 1. Monooxygenase activity $v$ s alkyl phosphocholine (PC) concentration profiles (see Materials and Methods).

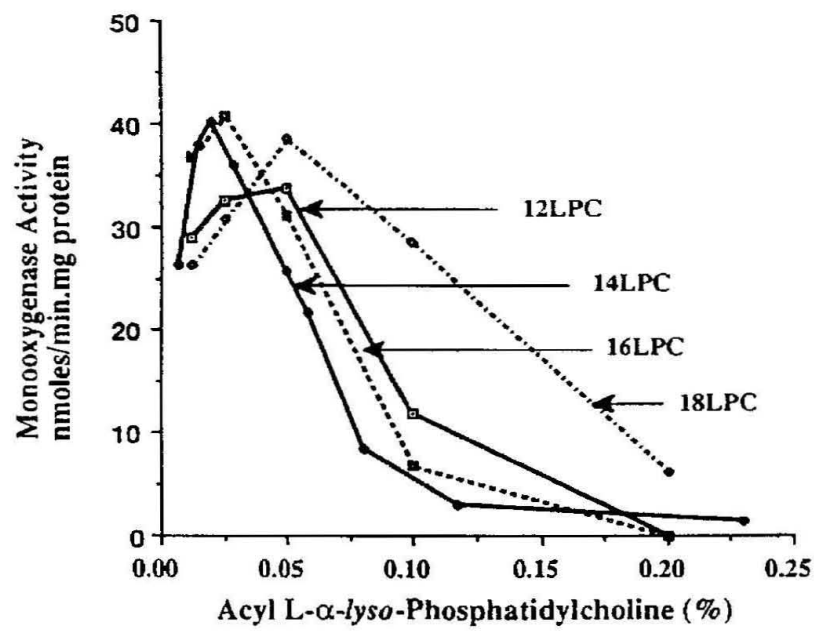

Figure 2. Monooxygenase activity vs acyl L- $\alpha$-lyso-phosphatidyl-cholines (LPC) concentration profiles (see Materials and Methods)

and $0.5 \mathrm{mM} 6 \mathrm{MePH}_{4}$ as cofactor, and are illustrated in Figure 1 and 2 respectively. The reason for decreased enzyme activity at very low detergent concentrations was due to the lower solubility of batyl alcohol in the very low concentrations of detergent as demonstrated by the turbidity of the solutions. The profiles show that $12 \mathrm{PC}$ and $18 \mathrm{LPC}$ in each set stand out, but all the maximum enzyme velocities (35-45 nmole/min.mg protein) were somewhat higher than the maximum activity of $27.6 \mathrm{nmole} / \mathrm{min} . \mathrm{mg}$ protein for the maximum initial rate in $2.3 \mathrm{mM}$ Mega-10 under the same conditions $(0.1 \mathrm{mM}$ batyl alcohol, 0.5 $\mathrm{mM} 6-\mathrm{MePH}_{4}$ and $0.1 \mathrm{M}$ Tris- $\mathrm{HCl}$ at $\mathrm{pH}$ 7.5). This suggests that the ether-lipid substrate in the mixed micelles was more accessible to the monooxygenase, or the detergent may have modified the nature of the enzyme such that the activity increased.
Inhibition of glycerylether monooxygenase by detergents

All the phosphocholines and phospatidylcholines inhibit monooxygenase activity at higher detergent concentrations, as was observed with other detergents, e.g. Mega-10, TritonX - 100, sodium deoxycholate (3). However, unlike Mega-10 which started to inhibit the monooxygenase at a concentration threshold immediately above the $\mathrm{CMC}$, all the cholines had maximum enzyme activities well above their respective $\mathrm{CMC}$ values. The threshold concentrations for $12 \mathrm{PC}, 14 \mathrm{PC}, 16 \mathrm{PC}$ and $18 \mathrm{PC}$ are $1.63 \mathrm{mM}$ $(0.07 \%), 0.832 \mathrm{mM}(0.035 \%), 0.348 \mathrm{mM}(0.02 \%)$ and $0.600 \mathrm{mM}(0.035 \%)$ respectively (see Figure 1 and 2). The threshold concentrations for $12 \mathrm{LPC}, 14 \mathrm{LPC}$, $16 \mathrm{LPC}$ and $18 \mathrm{LPC}$ are $1.22 \mathrm{mM}(0.05 \%), 0.660 \mathrm{mM}$ $(0.29 \%), 0.540 \mathrm{mM}(0.025 \%)$ and $1.02 \mathrm{mM}(0.05 \%)$ respectively. This implies that below their threshold concentrations the detergent micelles are passively associated with the microsomal membrane and do not seriously affect enzyme activity. However, it is possible that the inhibiting species above the threshold concentrations of these detergents are detergent micelles with higher aggregation numbers because $c o$ mpetitive inhibition was observed (see below). Alternatively, inhibition of the enzyme above the threshold concentrations may be due to disruption, by the detergent, of the microsomal lipid associated with the monooxygenase. Tetradecyl phosphocholine (14 PC) had been used as a detergent to solubilise ether-lipid substrates, including batyl alcohol, by dissolving them in this detergent at a concentration of $7 \mathrm{mg} / \mathrm{ml}$, i.e. $0.7 \%, c a 20 \mathrm{mM}(7,8)$. The solubilised substrates were used in the coupled (continuous spectrophotometric) assay with DHPR and NADH. The authors had not stated the final concentration of $14 \mathrm{PC}$ in their assay solutions, but if the dilution was tenfold, i.e. $0.07 \%$, then considerable inhibition of monooxygenase activity must have resulted (see Figure 1). This was reflected in the low monooxygenase activity that had been observed ( 7.4 nmoles/min.mg protein for batyl alcohol) (8).

The kinetics of inhibition of glyceryl-ether monooxygenase with batyl alcohol as substrate and 6$\mathrm{MePH}_{4}$ as cofactor by $14 \mathrm{PC}, 14 \mathrm{LPC}, 16 \mathrm{PC}$ and 16 LPC were investigated. The data were evaluated as described for Mega-10 (6), and the threshold concentrations, i.e. the concetrations at which enzyme inhibition begins, were taken as zero detergent concentration. Only by setting these values as zero all the data could be evaluated satisfactorily by computer analysis (12). The data fitted best for competitive inhibition and corresponded with the respective Lineweaver-Burk plots (see Figure 3 for 14PC). The ap- 


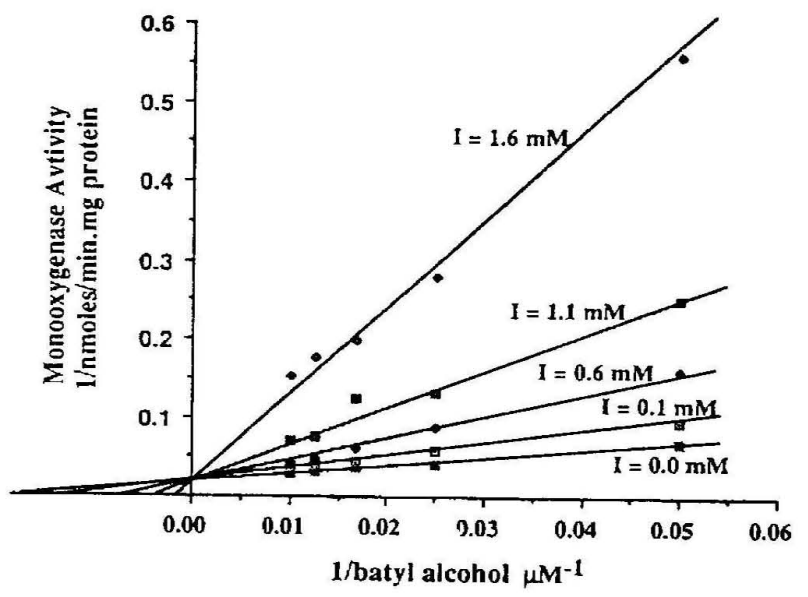

Figure 3. Lineweaver-Burk plots for the inhibition of glyceryl-ether monooxygenase by $14 \mathrm{LPC}$ using RS-batyl alcohol as substrate and $0.5 \mathrm{mM} \mathrm{6-} \mathrm{MePH}_{4}$ as cofactor in $0.1 \mathrm{M}$ Tris- $\mathrm{HCl}$ pH 7.5.

Table 2. Inhibition of glyceryl-ether monooxygenase by $\mathrm{C} 14$ and $\mathrm{C} 16$ phosphocholines and L- $\alpha$-lyso-cholines using batyl alcohol as substrate and $6-\mathrm{MePH}_{4}(0.5 \mathrm{mM})$ as cofactor in $0.1 \mathrm{M}$ Tris- $\mathrm{HCl} \mathrm{pH} 7.5$ and $25^{\circ} \mathrm{C}$.

\begin{tabular}{lc}
\hline \hline \multicolumn{1}{c}{ Competitive inhibitor } & $\begin{array}{c}\text { Apparent } \mathrm{K}_{\mathrm{i}} \\
(\mu \mathrm{M})\end{array}$ \\
\hline $\begin{array}{l}\text { Tetradecyl phosphocholine [14 PC] } \\
\text { Myristoyl L- } \alpha \text {-lyso-phosphatidylcho- }\end{array}$ & $320( \pm 72)$ \\
$\quad$ line [14 LPC] & $326( \pm 36)$ \\
$\begin{array}{l}\text { Hexadecyl phosphocholine [16 PC] } \\
\text { Palmitoyl L- } \alpha-l y s o \text {-phosphatidylcholine } \\
\quad[16 \text { LPC] }\end{array}$ & $365( \pm 63)$ \\
\hline
\end{tabular}

parent $\mathrm{Ki}$ values using batyl alcohol as substrate were very similar, within experimental error, and in the range $316-365 \mu \mathrm{M}$ (Table 2). By analogy the Ki values for $12 \mathrm{PC}, 12 \mathrm{LPC}, 18 \mathrm{PC}$ and $18 \mathrm{LPC}$ can be taken as being similar to the $\mathrm{C} 14$ and $\mathrm{C} 16$ analogues and that inhibition would be competitive. These inhibitions were different from the value for Mega-10 (using batyl alcohol and $0.5 \mathrm{mM} 6-\mathrm{MePH}_{4}$ in $0.1 \mathrm{M}$ Tris- $\mathrm{HCl}$ at $\mathrm{pH} 7.5$ ) in magnitude (apparent $\mathrm{Ki} 1.74$ $\pm 0.37 \mathrm{mM}$ ) and in type (noncompetitive). Clearly the various choline micelles were interacting with the monooxygenase most probably at the active site and competing with mixed micelles containing the etherlipid substrate.

\section{Kinetic parameters}

The apparent $\mathrm{Km}$ and Vmax values were determined for batyl alcohol with $0.5 \mathrm{mM} 6-\mathrm{MePH}_{4}$ (at or near saturating) in $0.1 \mathrm{M}$ Tris- $\mathrm{HCl}$ buffer at $\mathrm{pH} 7.5$ in the presence of all the PC and LPC detergents at concentrations near or below the respective threshold concentrations. The parameters together with the respective detergent concentrations (all above the CMC values) are in Table 3 . The apparent $\mathrm{Km}$ values were in the range 24-44 $\mu \mathrm{M}$ and the apparent Vmax values were in the range $46-64$ nmoles/min.mg protein. The similarities of these kinetic parameters suggest that the mechanism by which the ether-lipid substrate was directed to the active site of the monooxygenase was the same for these detergent solutions. The $\mathrm{Km}$ values were of the same magnitude as that for batyl alcohol in Mega-10 (at $2.3 \mathrm{mM}$, below the $\mathrm{CMC}$ ), i.e. $25 \mu \mathrm{M}$, whereas the apparent $\mathrm{Vmax}$ values were consistently higher by a factor of about 2 (see Table 3 and Figure 1 and 2). If the $\mathrm{Km}$ values were taken as a rough indication of the binding of batyl alcohol at the active site of the monooxygenase, then the various detergents, ionic and non-ionic, do not appear to affect this interaction seriously. The turnover of batyl alcohol (as deduced from the apparent Vmax values) was more efficient with the choline detergents than with Mega-10. This can be

Table 3. Kinetic parameters for glyceryl-ether monooxygenase with batyl alcohol as substrate and 6- $\mathrm{MePH}_{4}(0.5 \mathrm{mM})$ as cofactor in $0.1 \mathrm{M}$ Tris- $\mathrm{HCl}(\mathrm{pH} 7.5)$ at $25^{\circ} \mathrm{C} .3$

\begin{tabular}{ccccc}
\hline \hline & $12 \mathrm{PC}$ & $14 \mathrm{PC}$ & $16 \mathrm{PC}$ & $18 \mathrm{PC}$ \\
\hline Concn of detergent, $\mu \mathrm{M}$ & $815(0.035 \%)$ & $382(0.016 \%)$ & $348(0.02 \%)$ & $600(0.035 \%)$ \\
$\mathrm{Km}, \mu \mathrm{M}$ & $27.7( \pm 2.0)$ & $27.0( \pm 2.6)$ & $30.1( \pm 2.8)$ & $36.3( \pm 2.4)$ \\
Vmax & $48.7( \pm 1.1)$ & $46.1( \pm 1.9)$ & $64.2( \pm 2.0)$ & $60.6( \pm 1.5)$ \\
nmoles/min.mg protein & & & & $18 \mathrm{LPC}$ \\
\hline Concn of detergent, $\mu \mathrm{M}$ & $979(0.04 \%)$ & $332(0.0145 \%)$ & $538(0.025 \%)$ & $1170(0.05 \%)$ \\
Km, $\mu \mathrm{M}$ & $33.8( \pm 3.8)$ & $27.4( \pm 2.7)$ & $24.0(2.7 \%)$ & $43.7( \pm 4.3 \%)$ \\
Vmax & $54.4( \pm 2.2)$ & $48.5( \pm 0.8)$ & $50.0( \pm 2.2)$ & $61.0( \pm 2.5)$ \\
\end{tabular}

With Mega-10 [2.3 mM, 0.08\%] as detergent the $\mathrm{Km}$ and Vmax values were $25.1( \pm 2.9) \mu \mathrm{M}$ and $27.6 \mathrm{nmoles} / \mathrm{min} . \mathrm{mg}$ protein. All $\mathrm{Km}$ and Vmax values are apparent. 
attributed to greater interaction of the detergents with the monooxygenase and/or the microsomal membrane. Studies with the microsomal-free monooxygenase are in progress, as well as analytical ultracentrigugation studies of the micelle composition of these detergents.

\section{Acknowledgements}

We thank the Australian National University for a Visiting Fellowship (to H.T.) and a Visiting Scholarship (to T.K.), and Mrs T. Culnane for running the NMR spectra.

\section{References}

1. Teitz A, Lindberg M, Kennedy EP. A new pteridine-requiring system for the oxidation of glyceryl ethers. J. Biol. Chem. $1964: 239: 4081-4090$.

2. Armarego WLF, Kosar-Hashemi B. Rat liver preparations with glyceryl etherase activity. In : Curtius H.-Ch, Ghisla $\mathrm{S}$, Blau N, eds. Chemistry and biology of pteridines and folic acid derivatives. Berlin, New York : Walter de Gruyter. 1989: 620-623.

3. Kosar-Hashemi B, Armarego WLF. A convenient spectrophotometric method for measuring the kinetic parameters of glyceryl-ether monooxygenase (EC 1.14.16.5). Biol. Chem. Hoppe-Seyler $1993: 374:$ 9-25.
4. Kosar-Hashemi B, Taguchi H, Armarego WLF. Glycerylether monooxygenase Part V. Some aspects of the stoichiometry. Pteridines $1994: 5: 1-7$.

5. Hildreth JEK N-D-Gluco-N-methylalkanamide compounds, a new class of non-ionic detergents for membrane biochemistry. Biochem J. $1982: 207: 363-366$

6. Taguchi H, Kosar-Hashemi B, Paal B, Yang N, Armarego WLF. Glyceryl-ether monooxygenase (EC 1.14.16.5) Part VI. Nature of the glyceryl-ether lipid substrates in aqueous buffer. Biol. Chem. Hoppe-Seyler 1994 : 375 : 329-334.

7. Koetting J, Unger C, Eibl H. A continuous assay for Oalkylglycerol monooxygenase (EC 1.14.16.5). Lipids 1987 : $22: 824-830$.

8 Köting J, Unger C, Eibl H. Substrate specificity of O-alkylglycerol monooxygenase (EC 1.14.16.5), solubilized from rat liver microsomes. Lipids $1987: 22: 831-835$.

9. Armarego WLF, Schou H. Pterins. Part 2. Stereochemistry of catalytic reduction of 6-methyl- and 6, 7-dimethyl-pterin and of 2, 4-diamino-6-methylpteridine. J. C. S. Perkin Transactions 1 1977: 2529-2536.

10. de Vendittis E, Palumbo G, Parlato G, Bocchini V. A fluorimetric method for the estimation of the critical micelle concentration of surfactants. Anal Biochem 1981: 115: 278-286

11. Eibl H, Engel J. in Alkyl phosphocholines : New Drugs in Cancer Therapy (Eibl H, Higard P, Unger C, eds) Krager, Basel, 1992 : pp 1-5

12. Cleland WW. Statistical Analysis of Enzyme Kinetic Data. Methods Enzymol 1979: 63:103-138 